\title{
Trichostatin A Improves Preimplantation Development of Bovine Cloned Embryos and Alters Expression of Epigenetic and Pluripotency Genes in Cloned Blastocysts
}

\author{
Hyun Ju $\mathrm{OH}^{1)}$, Tae Hee LEE ${ }^{2}$, Ji Hyun LEE ${ }^{3)}$ and Byeong Chun LEE ${ }^{1)^{*}}$ \\ ${ }^{1)}$ Department of Theriogenology and Biotechnology, College of Veterinary Medicine, Seoul National University, Seoul, 151-744, Korea \\ 2) Richard Montgomery High School, Rockville, MD, U.S.A. \\ ${ }^{3)}$ College of Arts and Science, University of Pennsylvania, Philadelphia, PA, U.S.A.
}

(Received 11 November 2011/Accepted 4 June 2012/Published online in J-STAGE 18 June 2012)

ABSTRACT. We investigated the effects of exposure time and concentration of trichostatin A (TSA) on in vitro development and quality of bovine SCNT embryos. At multiple time points, the relative expression of genes related to pluripotency and reprogramming was analyzed in order to assess the quality of preimplantation embryos cultured in media with TSA using real-time PCR. Development into blastocysts was higher in $100 \mathrm{nM}$ TSA than in controls (35.96 vs. $28.30 \%, P<0.05)$. Study of $100 \mathrm{nM}$ TSA exposure time showed development into blastocysts was higher during both short-term and long-term exposure than in controls ( 36.17 and 34.04 vs. 23.45\%), but there was no significant difference between TSA groups. Nanog expression in blastocysts after long-term TSA exposure was similar to that in IVF blastocysts and greater than in controls and short-term exposed embryos. The Oct4 levels in the short-term exposure group were similar to those of IVF blastocysts, while Oct4 expression in long-term exposed embryos was significantly higher than in other groups. Measurement of DNMT1 and HDAC1 in blastocysts showed a similar expression profile among IVF and TSA groups regardless of treatment duration. In conclusion, this study suggests that TSA treatment after SCNT in bovine embryos can improve in vitro development of embryos by increasing the blastocysts formation and positive reprogramming of the reconstructed embryo genome caused by downregulation of DNA methylation and up-regulation of pluripotency.

KEY WORDS: blastocysts, bovine SCNT, pluripotency, reprogramming, Trichostatin A.

doi: 10.1292/jvms.11-0510; J. Vet. Med. Sci. 74(11): 1409-1415, 2012

The somatic cell nuclear transfer (SCNT) technique is promising for applications such as species preservation, livestock propagation and cell therapy for medical treatment $[35,36]$. Although cloning mammals by SCNT into oocyte cytoplasts have successfully produced offspring in a variety of species over the past decade, SCNT has low efficiency and a high frequency of developmental abnormalities [8, 30]. One of the underlying problems in SCNT embryos is incomplete or incorrect status of epigenetic reprogramming such as DNA methylation or histone modification [28, 44].

For improving this acetylation reprogramming, SCNT studies have reported epigenetic reprogramming modification using histone deacetylase inhibitor in activation or culture of reconstructed oocytes. Epigenetic reprogramming represents an important feature of nuclear reprogramming in SCNT embryos [15, 28]. Dynamic interactions exist between DNA methylation and acetylation in the aminoterminal domains of core histones in order to regulate DNA functions and control gene expression [22, 34, 42]. Indeed, the regulation of genes coordinating embryo and fetal development depends on important remodeling in chromatin structure and DNA [12, 29].

Trichostatin A (TSA) is a histone deacetylase inhibitor

\footnotetext{
*CORRESPONDENCE TO: LEe, B.-C., Department of Theriogenology and Biotechnology, College of Veterinary Medicine, Seoul National University, 599 Gwanangno, Gwanak-gu, Seoul 151-742, Korea.

e-mail: bclee@snu.ac.kr
}

(C)2012 The Japanese Society of Veterinary Science that reversibly binds the active catalytic site of HDACs causing acetylated histones to accumulate in cells [26] and reduces DNA methylation and expression of DNA methyltransferases (DNMTs) in reconstructed embryos [24, 40]. Recently, treatment of SCNT cloned mouse embryos with TSA significantly improved their in vivo developmental competence $[19,20,31]$. Since then, significant improvements in SCNT efficiency through TSA treatment were also reported in the pig, bovine and rabbit $[15,23,32]$. Several studies demonstrated that histone acetylation of TSAtreated cloned embryos showed a similar pattern to that of normal embryos in the mouse, pig, bovine and rabbit [15, 23, 32, 37]. However, despite the obvious beneficial effects of TSA on cloning efficiency in some species, the optimal concentration and exposure time for TSA treatment are not yet clear. Different studies have used TSA using slightly different protocols. In bovine, Akagi et al. reported improved blastocyst formation when SCNT embryos were cultured in $5 \mathrm{nM}$ TSA for $20 \mathrm{hr}$ after activation [1]. On the other hand, Lager et al. obtained a similar result when using $50 \mathrm{nM}$ TSA and applying the treatment for $13 \mathrm{hr}$ [15].

To help resolve these discrepancies and establish optima for bovine cloned embryos, this study aimed to investigate 2 things. Firstly, we aimed to see what effect the TSA exposure time and concentration had on in vitro development and quality of bovine SCNT embryos. Secondly, we wanted to confirm that the expression of the following genes in cloned blastocysts was derived from TSA exposure: 1) HDAC1 and DNMT1, which are associated with epigenetic modification, because histone acetylation and DNA meth- 
ylation are important epigenetic factors that modify chromatin structure, 2) Oct4 and Nanog, which are associated with pluripotency and early embryonic development.

\section{MATERIALS AND METHODS}

Chemicals: Unless otherwise indicated, chemicals were purchased from Sigma-Aldrich Corp. (St. Louis, MO, U.S.A.).

Preparation of in vitro matured oocytes and recipient oocytes: Bovine ovaries were collected from a local slaughterhouse and transported to the laboratory within $2 \mathrm{hr}$ at $30-35^{\circ} \mathrm{C}$ in $0.9 \%(\mathrm{v} / \mathrm{v}) \mathrm{NaCl}$ solution. Cumulus-oocyte complexes (COCs) were aspirated from $2-8 \mathrm{~mm}$ follicles using a $10 \mathrm{~m} l$ disposable syringe with an 18 -gauge needle. The COCs with layers of compact cumulus cells were selected and washed three times in HEPES-buffered tissue culture medium-199 (TCM-199; Invitrogen Coporation, Carlsbad, CA, U.S.A.) supplemented with $10 \% \mathrm{FBS}, 2 \mathrm{mM} \mathrm{NaHCO}_{3}$, $5 \mathrm{mg} / \mathrm{m} l$ BSA and $1 \%$ penicillin-streptomycin (v/v). For preparation of in vitro matured oocytes, 30-40 COCs were cultured in 4-well dishes (Falcon, Becton, Dickinson U.K. Limited, Plymouth, UK) for $22 \mathrm{hr}$ in $500 \mu \mathrm{l}$ of TCM-199 supplemented with $0.005 \mathrm{IU} / \mathrm{m} l$ FSH (Antrin, Teikoku, Japan) and $1 \mu \mathrm{g} / \mathrm{m} l 17 \beta$-estradiol at $39^{\circ} \mathrm{C}$ in a humidified atmosphere of $5 \% \mathrm{CO}_{2}$ in air $[6,16]$.

Preparation of donor cells: Fetal fibroblasts were isolated from fetuses on day 40 of gestation as previously described [16]. The head of the fetus was removed using iris scissors, and soft tissues such as the liver and intestines were discarded by scooping out with two watchmaker's forceps. After washing three times with DPBS (cat. no. 14190-144, Life Technologies, Rockville, MD, U.S.A.), the tissue was minced with a surgical blade on a $100-\mathrm{mm}$ culture dish (Becton Dickinson, Lincoln Park, NJ, U.S.A.). The minced fetal tissues and cells were cultured in Dulbecco's modified Eagle's medium (Invitrogen) supplemented with 10\% (v/v) FBS (Invitrogen), $1 \mathrm{mM}$ glutamine (Invitrogen), $25 \mathrm{mM}$ $\mathrm{NaHCO}_{3}$ and $1 \%(\mathrm{v} / \mathrm{v})$ minimal essential medium nonessential amino acid solution (Invitrogen) at $39^{\circ} \mathrm{C}$ in a humidified atmosphere of $5 \% \mathrm{CO}_{2}$ and $95 \%$ air. After 8 days, unattached clumps of cells or explants were removed and cultured further until confluent. Prior to SCNT, cells were thawed, cultured for 3-4 days until confluent and retrieved from the monolayer by trypsinization for $3 \mathrm{~min}$ [16]. In this study, we used only one fetal cell line to evaluate the concentration and exposure time of TSA in bovine SCNT embryos.

Somatic cell nuclear transfer: Cumulus cells of mature oocytes were removed by repeated pipetting in $0.1 \%(\mathrm{v} / \mathrm{v})$ hyaluronidase in HEPES-buffered TCM-199, and oocytes with a first polar body were selected. SCNT was performed as described in previous reports [5]. In brief, one fibroblast was deposited into the perivitelline space of an enucleated oocyte. The donor cell-cytoplast couplet was fused with two pulses of direct current, 35-40 V/cm, for $15 \mu \mathrm{sec}$ each using an Electro Cell Fusion apparatus (NEPA GENE corporation, Limited, Chiba, Japan). At $4 \mathrm{hr}$ after fusion, fused oocytes were activated by treatment with $5 \mu \mathrm{M}$ ionomycin for 4 min and then $1.9 \mathrm{mM}$ dimethylaminopurine (DMAP) for $4 \mathrm{hr}$. In order to monitor in vitro development, cloned embryos of all groups were cultured in $30 \mu \mathrm{l}$ microdrops of modified synthetic oviductal fluid (mSOF) [5] under mineral oil for 8 days at $39 \circ \mathrm{C}$ in a humidified atmosphere of $5 \% \mathrm{CO}_{2}, 5 \% \mathrm{O}_{2}$ and $90 \% \mathrm{~N}_{2}$.

In vitro fertilization: For IVF of oocytes, frozen-thawed spermatozoa were prepared by a swim-up method [38]. IVF was performed as described in previous reports [45]. Shortly after $22 \mathrm{hr}$ of maturation culture, COCs were inseminated with $1 \times 10^{6}$ motile spermatozoa $/ \mathrm{m} l$. Co-incubation of gametes was performed in $30 \mu \mathrm{l}$ microdrops of mSOF for $18 \mathrm{hr}$ under mineral oil. A group of 6 or 7 zygotes was cultured in a $30 \mu \mathrm{l}$ microdrop of $\mathrm{mSOF}$ overlaid with mineral oil for 8 days.

Total RNA extraction and $c D N A$ synthesis: The blastocysts derived from SCNT or IVF were washed three times with PBS (Invitrogen), transferred into $5 \mu l$ of DEPC (diethyl pyrocarbonate) treated water and stored at $-80^{\circ} \mathrm{C}$ until RNA extraction. Total RNA was extracted using the easy-spin ${ }^{\mathrm{TM}}$ Total RNA Extraction Kit (iNtRON Biotechnology, Inc., Kyunggi, Korea) following the manufacturer's protocol. The isolated total RNAs were quantified using a photospectrometer (NanoDrop 2000, Thermo Fisher Scientific Inc. Waltham, MA, U.S.A.) and immediately stored at $-80^{\circ} \mathrm{C}$ until cDNA synthesis. The cDNA was synthesized from $1 \mu \mathrm{g}$ of total RNA from each sample, and $1 \mu l$ of oligo $(\mathrm{dt})_{20}$ primers was diluted to a final volume of $8 \mu l$ in DEPC-treated

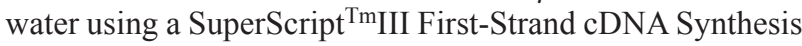
kit (Invitrogen) by following the manufacturer's instructions. The synthesized cDNAs were stored at $-20^{\circ} \mathrm{C}$ until they were used for real-time PCR.

Real-time PCR: Real-time PCR was performed using an ABI 7300 Real-Time PCR System (Applied Biosystems, Forest City, CA, U.S.A.) and SYBR Green interaction dye (Takara Bio U.S.A. Inc., Mountain View, CA, U.S.A.) following the manufacturer's instructions with minor modification. A total of $22 \mu l$ of PCR reaction mixture was made using $2 \mu l$ cDNA, $1 \mu l$ forward primer, $1 \mu l$ reverse primer, $8 \mu l$ SYBR premix EX Taq, $0.4 \mu l$ ROX reference dye and $10 \mu l$ of Nuclease-free water (Ambion Inc., Austin, TX, U.S.A.). The thermal profile for real-time PCR was $95^{\circ} \mathrm{C}$ for $10 \mathrm{~min}$, followed by 40 cycles of $95^{\circ} \mathrm{C}$ for $10 \mathrm{sec}, 60^{\circ} \mathrm{C}$ for $20 \mathrm{sec}$, and $72^{\circ} \mathrm{C}$ for $40 \mathrm{sec}$. All primer set sequences shown in Table 1 were standardized according to a standard curve. Three replicates per plate were done for each sample, and each experiment was repeated with 3 different samples.

Nuclear donor cell and somatic cell nuclear transfer: A bovine fetal fibroblast was placed into the perivitelline space of an enucleated oocyte and fused by electrical stimulation. The fused couplets were activated by $4 \mathrm{~min}$ incubation in 5 $\mu \mathrm{M}$ ionomycin, followed by $4 \mathrm{hr}$ of culture in $1.9 \mathrm{mM} 6$-dimethylaminopurine with or without TSA $(0,50$ or $100 \mathrm{nM})$. The SCNT embryos were subsequently cultured in $\mathrm{mSOF}$ for 8 days.

Experimental design: Experiment 1 was performed to investigate the effect of different concentrations of TSA on in vitro culture of SCNT embryos. The fused couplets were 
activated by 4 min incubation in $10 \mu \mathrm{M}$ ionomycin, followed by $4 \mathrm{hr}$ of culture in DMAP with or without TSA $(0,50$ or $100 \mathrm{nM}$ ). The SCNT embryos were subsequently cultured in $\mathrm{mSOF}$ for 8 days. In order to evaluate embryo quality, blastocysts were stained with Hoechst 33342 and observed under an epifluorescence microscope. Photographs were taken, and stained nuclei were counted to determine the total cell number. Experiment 2 was performed to investigate the effect of TSA exposure duration on in vitro development of SCNT embryos. After chemical activation of cloned embryos using $10 \mu \mathrm{M}$ ionomycin for $4 \mathrm{~min}$, they were divided into three groups for testing: 1) a control group was cultured for $4 \mathrm{hr}$ in 6-DMAP without TSA; 2) TSA short-term (TS) group was cultured for $4 \mathrm{hr}$ in 6-DMAP containing $100 \mathrm{nM}$ TSA; and 3) TSA long-term (TL) group was cultured continually for $16 \mathrm{hr}$ in mSOF containing $100 \mathrm{nM}$ TSA after culture for $4 \mathrm{hr}$ in 6-DMAP containing $100 \mathrm{nM}$ TSA. After TSA treatment, cloned embryos of the TS and TL groups were then cultured in mSOF without TSA for 8 days. Developmental competence of cloned embryos was assessed by blastocyst formation; fifteen blastocysts were randomly pooled in each group for RNA extraction. In experiment 3, based on the results of experiment 2 , the relative expression of four genes (Nanog, Oct4, DMNT1, and HDAC1) related to pluripotency and reprogramming was analyzed to assess the quality of preimplantation embryos cultured in the medium with TSA using real-time PCR (Applied Biosystems). Relative expression levels of each gene were represented as the ratio of each gene to that of the b-actin gene.

Statistical analysis: All experiments were replicated at least three times, and embryos were randomly allocated into each treatment group. Values of each parameter were subjected to ANOVA in a generalized linear model (PROCGLM) of SAS (Anon, 1990). When model effect was significant in each parameter, each value after the treatment was compared by the least-squares method. A P value of less than 0.05 was considered to indicate significant difference among the treatment groups.

\section{RESULTS}

The effect of different concentrations of TSA on in vitro development of SCNT embryos: The effect of different concentrations of TSA on in vitro development of SCNT embryos was examined. As shown in Table 2, developmental competence to blastocysts was higher in $100 \mathrm{nM}$ TSA than in the control group $(35.96 \pm 0.6 \%$ vs. $28.30 \pm 1.3 \%$, $P<0.05)$. No significant differences in the 2-cell and morula stages were observed among treatment groups. In terms of development to the hatching stage of blastocysts, the TSA 100 group $(20.16 \pm 1.1 \%)$ at 8 days showed significantly higher development compared with the control and TSA 50 groups $(12.28 \pm 1.0 \%$ and $12.39 \pm 0.5 \%$, respectively; $P<0.05)$. Total cell numbers of blastocysts derived from TSA 100 were significantly higher (Table $3, P<0.05$ ) than in TSA $50(116 \pm 5.3$ vs. $100 \pm 5.6$, respectively), whereas there was no significant difference between the control and TSA 100. Figure 1 shows representative stained blastocysts in each group.

The effect of TSA exposure time on in vitro development of SCNT embryos: No difference in cleavage in shown in Table 2, but there were more 4-cells stage embryos with both TSA

Table 1. Primer sequences for transcription detection of bovine genes

\begin{tabular}{|c|c|c|c|}
\hline Gene & Primer sequences $\left(5^{\prime} \rightarrow 3^{\prime}\right)$ & GenBank No. & Product size (bp) \\
\hline beta-actin & $\begin{array}{l}\text { F-GTCCACCGCAAATGCTTCTA } \\
\text { R-CGTTTTCTGCGCAAGTTAGG }\end{array}$ & NM_173979 & 81 \\
\hline HDAC1 & $\begin{array}{l}\text { F-ATTGACGACGAGTCCTATGAG } \\
\text { R-ATGCCCTTTGATGGTCAGATT }\end{array}$ & NM_001037444 & 150 \\
\hline DNMT1 & $\begin{array}{l}\text { F- CGATGACGAGGAAGTGGATG } \\
\text { R- CCAACCCAAGAGATCCGATT }\end{array}$ & NM_182651 & 109 \\
\hline Nanog & $\begin{array}{l}\text { F-TAACCCCACGTGGAGCAACC } \\
\text { R-GGCACCAGGCCTGACTGTTC }\end{array}$ & NM_001025344 & 77 \\
\hline Oct4 & $\begin{array}{l}\text { F-TCTGACTTCGCCTTCTCGCC } \\
\text { R-GGAGGCCCTTGGAAGCTCA }\end{array}$ & NM_174580 & 107 \\
\hline
\end{tabular}

Table 2. Effect of different concentrations of TSA on in vitro development of bovine SCNT embryos

\begin{tabular}{|c|c|c|c|c|c|c|c|}
\hline Trea & $\begin{array}{l}\text { No. of } \\
\text { oocytes }\end{array}$ & $\begin{array}{c}\text { No. of 2-cells } \\
(\text { mean } \% \pm \text { SEM) }\end{array}$ & $\begin{array}{c}\text { No. of 4-cells } \\
(\text { mean } \% \pm \text { SEM) }\end{array}$ & $\begin{array}{c}\text { No. of morulae } \\
(\text { mean } \% \pm \text { SEM) }\end{array}$ & $\begin{array}{l}\text { Total no. of BLs } \\
(\text { mean } \% \pm \text { SEM) }\end{array}$ & $\begin{array}{l}\text { No. of expanded BLs } \\
\text { (mean } \% \pm \text { SEM) }\end{array}$ & $\begin{array}{r}\text { No. } \\
(\mathrm{m}\end{array}$ \\
\hline & 11 & a) & & a) & & a) & \\
\hline & 11 & ${ }^{1} 11^{b}$ ) & o) & $.8)^{\mathrm{a}, \mathrm{b})}$ & $2.2)^{\mathrm{a}, \mathrm{b})}$ & 10( & $0.5)^{b)}$ \\
\hline $\mathrm{TS}$ & 16 & $2(88.31 \pm 1.6)^{a, b)}$ & $3(79.57 \pm 2.1)^{\mathrm{a})}$ & $3(36.55=$ & $\left.42(35.96 \pm 0.6)^{\mathrm{a}}\right)$ & $10(15.79=$ & $22(20.16 \pm 1.1)^{\mathrm{a})}$ \\
\hline
\end{tabular}

a,b) Within the same column, values with different superscripts are significantly different $(P<0.05)$. The experiments were replicated at least three times.

Control=culture for $4 \mathrm{hr}$ in 6-DMAP without TSA

TSA $50=$ culture for $4 \mathrm{hr}$ in 6 -DMAP containing $50 \mathrm{nM}$ TSA

TSA $100=$ culture for $4 \mathrm{hr}$ in 6-DMAP containing $100 \mathrm{nM}$ TSA BL=blastocyst 
Table 3. Effect of different concentrations of TSA on total cell number of bovine SCNT blastocysts

\begin{tabular}{|c|c|c|c|}
\hline \multirow{3}{*}{ Treatment } & \multicolumn{3}{|c|}{ Mean cell numbers per blastocyst (Mean \pm SEM) } \\
\hline & \multicolumn{2}{|c|}{ Stage of the blastocysts } & \multirow{2}{*}{ All blastocysts } \\
\hline & Expanded blastocyst & Hatching blastocyst & \\
\hline Control & $87 \pm 4.7^{\mathrm{a})}$ & $143 \pm 6.5^{\mathrm{a})}$ & $110 \pm 4.5^{\mathrm{a}, \mathrm{b})}$ \\
\hline TSA 50 & $85 \pm 5.8^{a)}$ & $143 \pm 8.2^{\mathrm{a})}$ & $100 \pm 5.6^{\mathrm{b})}$ \\
\hline TSA 100 & $94 \pm 6.3^{\mathrm{a})}$ & $149 \pm 6.5^{\mathrm{a})}$ & $116 \pm 5.3^{\mathrm{a})}$ \\
\hline
\end{tabular}

a,b) Within the same column, values with different superscripts are significantly different $(P<0.05)$. The experiments were replicated at least three times, and five embryos were examined in each experimental group.

Control=culture for $4 \mathrm{hr}$ in 6-DMAP without TSA

TSA $50=$ culture for $4 \mathrm{hr}$ in 6-DMAP containing $50 \mathrm{nM}$ TSA

TSA $100=$ culture for $4 \mathrm{hr}$ in 6-DMAP containing $100 \mathrm{nM}$ TSA
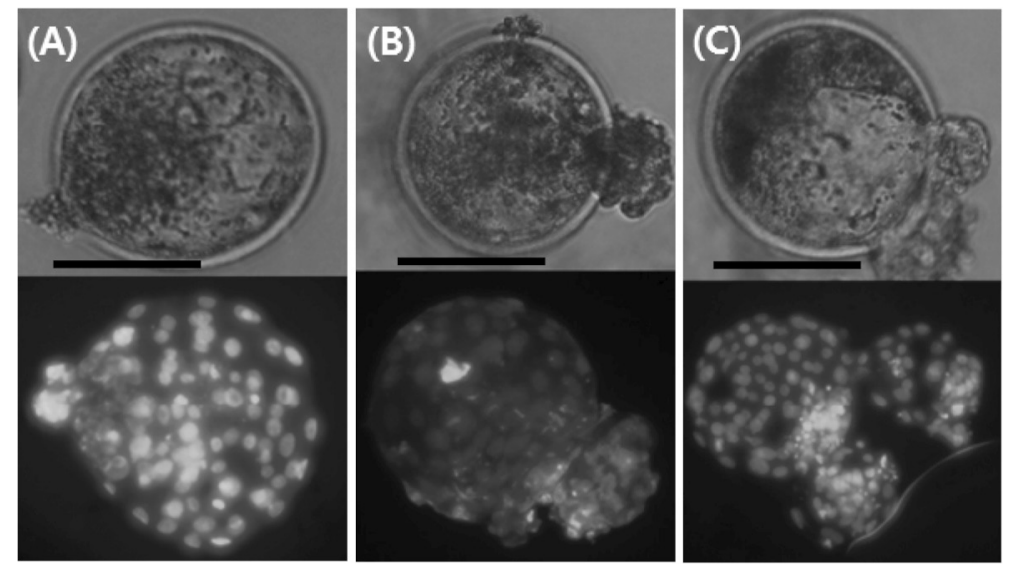

Fig.1. Cell number per blastocysts derived from each group. Representative photographs of Day 8 bovine blastocysts (200X) obtained in control (A), TSA $50 \mathrm{nM}$ treatment (B), and TSA $100 \mathrm{nM}$ treatment (C). Scale bar $=100 \mu \mathrm{m}$.

Table 4. Comparison between short-term (TS) and long-term (TL) culture with $100 \mathrm{nM}$ TSA treatment on in vitro development of bovine SCNT embryos

\begin{tabular}{ccccc}
\hline Treatment & $\begin{array}{c}\text { No. of } \\
\text { oocytes }\end{array}$ & $\begin{array}{c}\text { No. of 2-cell } \\
(\text { mean\% } \% \text { SEM) }\end{array}$ & $\begin{array}{c}\text { No. of morula } \\
(\text { mean\% } \% \text { SEM })\end{array}$ & $\begin{array}{c}\text { No. of blastocysts } \\
(\text { mean\% } \% \text { SEM })\end{array}$ \\
\hline Control & 77 & $65(84.94 \pm 4.7)^{\mathrm{a})}$ & $23(30.21 \pm 1.9)^{\mathrm{b})}$ & $18(23.45 \pm 1.2)^{\mathrm{b})}$ \\
TS & 76 & $73(96.45 \pm 1.2)^{\mathrm{a})}$ & $29(38.53 \pm 1.1)^{\mathrm{a})}$ & $28(36.17 \pm 2.3)^{\mathrm{a})}$ \\
TL & 76 & $67(89.43 \pm 5.4)^{\mathrm{a})}$ & $28(38.38 \pm 1.5)^{\mathrm{a})}$ & $26(34.04 \pm 1.5)^{\mathrm{a})}$ \\
\hline
\end{tabular}

a,b) Within the same column, values with different superscripts are significantly different $(P<0.05)$. The experiments were replicated at least four times.

$\mathrm{TS}=4 \mathrm{hr}$ treatment, $\mathrm{TL}=16 \mathrm{hr}$ treatment, at zygote stage

concentrations than in the control, and the blastocyst formation rate was highest with the $100 \mathrm{nM}$ TSA treatment (Table 2). Next, the effect of $100 \mathrm{nM}$ TSA exposure time on in vitro development of SCNT embryos was examined. As shown in Table 4, development in TS and TL to morulae (38.53 \pm 1.1 and $38.38 \pm 1.5 \%$, respectively) and blastocysts ( $36.17 \pm$ 2.3 and $34.04 \pm 1.5 \%$, respectively) was significantly higher than in controls $(30.21 \pm 1.9 \%$ morula and $23.45 \pm 1.2 \%$ blastocyst; $P<0.05$ ), but there was no significant difference between TSA groups.

The relative expression of four genes (Nanog, Oct4,
DNMT1, and HDAC1) related to pluripotency and reprogramming in blastocysts: The relative expression of genes related to pluripotency and reprogramming was analyzed in blastocysts derived from IVF, T0 (control), TS and TL groups. As shown in Fig. 2, Nanog expression in TL blastocysts was similar to that in IVF blastocysts and higher than that in control and TS blastocysts. Oct4 expression in IVF blastocysts was similar to that in the TS group, while Oct4 expression in TL blastocysts was significantly higher than in other groups $(P<0.05)$. In Fig. 2, measurement of DNMT1 and HDAC1 in blastocysts shows a similar expression pro- 
(A)

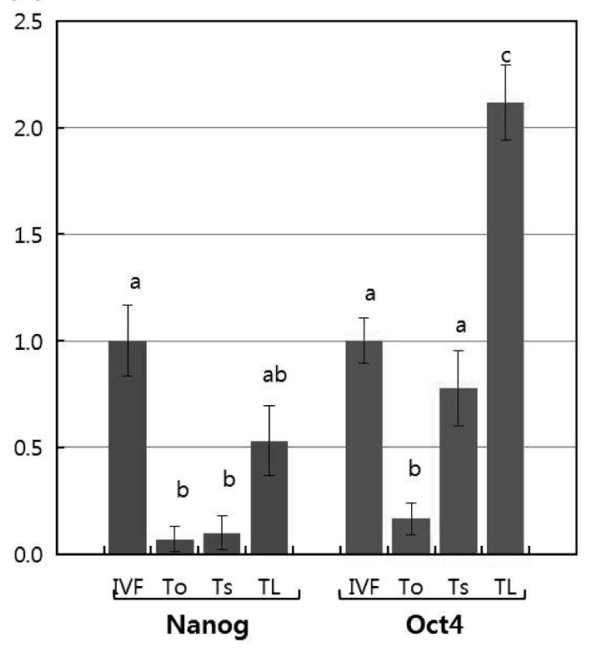

(B)

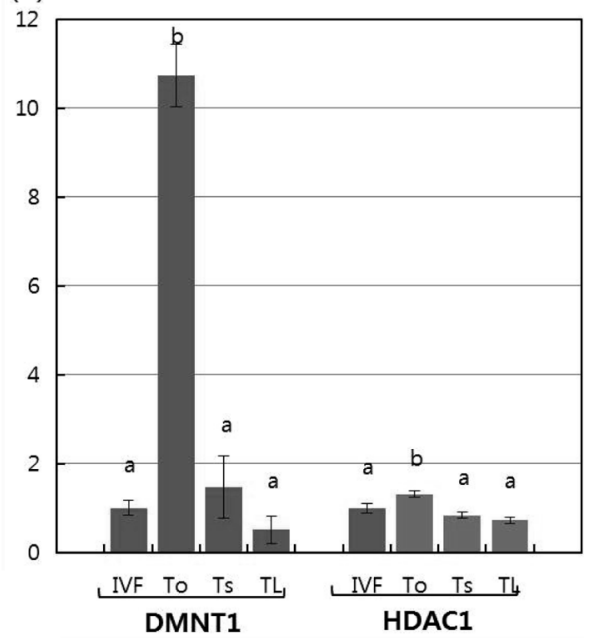

Fig. 2. Expression profiles of (A) Nanog and Oct4 related to pluripotency and (B) DNMT1 and HDAC1 related to reprogramming in blastocysts from IVF, control (T0), short-term TSA treatment (Ts) and long-term TSA treatment (TL). a,b Within the same column, values with different superscripts are significantly different $(P<0.05)$. Data presented as mean \pm SEM of at least three replicates and fifteen embryos were examined in each experimental group.

file among the IVF, TS and TL groups, whereas expression of DNMT1 and HDAC1 in controls was significantly higher than in the other three groups $(P<0.05)$.

\section{DISCUSSION}

This study was carried out to investigate the in vitro development and changes in gene expression of bovine cloned embryos during histone deacetylase inhibitor (HDACi) treatment after the activation procedure for SCNT. HDACis such as trichostatin A (TSA), valproic acid and scriptaid have been used for improving SCNT efficiency in various species, including pigs $[3,10,27]$, mice $[9,25]$, rabbits [33, $43]$ and cattle $[11,15]$. TSA increases the frequency of development to the blastocyst stage and improves blastocyst quality through induced hyperacetylation in cloned mouse [20, 31], bovine [15], porcine [7] and rabbit [33] embryos.

In the present study, we treated cloned bovine embryos with 0,50 and $100 \mathrm{nM}$ TSA, consistent with previous reports [20]. Treatment with $100 \mathrm{nM}$ TSA significantly increased embryo development to the blastocyst stage (Table 2), but prolonging treatment with $100 \mathrm{nM}$ TSA for $16 \mathrm{hr}$ did not improve the percentage of cleavage and development into blastocysts from the 2-cell stage compared with treatment for only $4 \mathrm{hr}$ (Table 4). However, cloned embryos treated with $100 \mathrm{nM}$ TSA, regardless of duration, showed significantly higher development compared with the control. In line with our results, a great number of SCNT studies in other species reported improved cloning efficiency when the embryos were cultured with TSA $[18,31,37]$. In particular, Kishigami et al. [20] first reported improved cloning efficiency when the SCNT embryos were treated with TSA. The present study suggests that treatment of NT embryos with the optimal concentration of TSA can improve their development through modification of their histone acetylatinn status.

With this in mind, we next investigated the expression of epigenetic- and pluripotency-related genes in normal, cloned and TSA-treated cloned bovine blastocysts. DNMT1 plays a key role in DNA methylation that is important in sustaining genomic stability and activating or suppressing gene expression through modification and regulation of the chromatin structure [21]. Also, DNMT1 is responsible for the regulation of transcription during embryonic development [41]. In the present study, abnormally high levels of DNMT1 transcripts in SCNT embryos (control) were appreciably suppressed by TSA down to levels similar to IVF blastocysts. In agreement with our results, TSA-treated cloned cat embryos showed significantly decreased methylation levels, but when treated with $100 \mathrm{nM}$ TSA they exhibited a normal pattern of acetylation and global loss of methylation similar to IVF counterparts [13]. Treatment of both donor cells and early cloned embryos with a combination of 5-aza-20-deoxycytidine and TSA changed not only modifies histone acetylation but also potentially induces DNA demethylation [39]. Otherwise, Iager et al. reported that there was no difference in DMNT1 and DMNT3a expression between blastocyst stage NT and IVF embryos [15]. The discrepancy may be due to differences in the protocol of TSA treatment, and the concentration and timing of treatment and exposure duration have been reported to have conflicting results on epigenetic modification of cloned blastocysts. We found that bovine NT blastocysts treated with TSA showed a significantly decreased expression level of HDAC1. It is believed that the decreased methylation and increased acetylation levels alter chromatin structure, facilitate nucleus reprogramming, and subsequently enhance the developmental competence of 
cloned embryos. Thus, TSA at the optimal concentration, regardless of treatment duration, may serve to reactivate DNA methylation-silenced genes, and subsequently improve the development of cloned embryos.

In our next experiment, we observed that TSA increased the expression levels of pluripotent genes in cloned embryos compared with control embryos. Oct4 and Nanog are regulators of pluripotency expressed during cleavage stages and are essential for differentiation of the blastocyst. In cloned mouse blastocysts, TSA treatment decreased the expression of DNA methylation-related genes and increased the expression of pluripotency-related genes [37]. Similarly, TSA treatment of pig embryos increased the expression of pluripotency- and imprinting-related genes at the blastocyst stage [7]. Other studies showed that the expression levels of Oct4 and Nanog were downregulated in cloned bovine blastocysts compared with their IVF counterparts, which is similar to the results in the present study $[2,4]$. We observed that the expression of Oct4 and Nanog genes was substantially upregulated in blastocysts, preferentially in cloned embryos that were treated with $100 \mathrm{nM}$ TSA for a long term. In short-term treatment with $100 \mathrm{nM}$ TSA, Oct4 gene expression was changed at a level similar to IVF counterparts, but Nanog expression was not upregulated in blastocysts treated for a short term. Oct4 can be altered in somatic cells by HDACis like as TSA, and Nanog could not be reactivated by these chemicals in trophoblast stem cells [14]. Although the difference in Nanog expression between the long-term and short-term groups cannot be exactly explained, short-term treatment with TSA might not be the optimal exposure duration of TSA for effective modification of Nanog gene. In ridents, extended exposure to TSA after activation altered the expression of genes related to pluripotency (OCT4, NANOG) and early embryonic development (FGF4, CDX2) in cloned embryos [17]. In addition, it was reported that nuclear reorganization of centromeric/pericentromeric sequences is often abnormal in SCNT embryos and is improved by TSA treatment [2525]. Modification of pluripotent genes like Oct4 and Nanog in SCNT embryos treated with a histone deacetylase inhibitor may hold the key to successful somatic cloning in mammals.

In conclusion, our results suggest that treatment with the optimal concentration of TSA improves the development of reconstructed bovine embryos. We recommend $100 \mathrm{nM}$ TSA for improving preimplantation development of bovine cloned embryos. This improvement may be due to enhanced epigenetic modification of somatic cells caused by TSA-induced hyperacetylation and demethylation and upregulation of pluripotency and embryonic growth after SCNT.

ACKNOWLEGMENTS. We thank to Dr Barry Bavister, $\mathrm{Ph}$. D. for editing the manuscript for English grammar. This study was supported by MKE (\#10033839-2011-13), BK21 for Veterinary Science, and IPET (\#109023-05-1-CG000/ \#311011-05-1-SB010) and RNL Bio.

\section{REFERENCES}

1. Akagi, S., Matsukawa, K., Mizutani, E., Fukunari, K., Kaneda,
M., Watanabe, S. and Takahashi, S. 2011. Treatment with a histone deacetylase inhibitor after nuclear transfer improves the preimplantation development of cloned bovine embryos. $J$. Reprod. Dev. 57: 120-126. [Medline] [CrossRef]

2. Aston, K. I., Li, G. P., Hicks, B. A., Sessions, B. R., Davis, A. P., Rickords, L. F., Stevens, J. R. and White, K. L. 2010. Abnormal levels of transcript abundance of developmentally important genes in various stages of preimplantation bovine somatic cell nuclear transfer embryos. Cell Reprogram 12: 23-32. [Medline] [CrossRef]

3. Beebe, L. F., McIlfatrick, S. J. and Nottle, M. B. 2009. Cytochalasin $\mathrm{B}$ and trichostatin a treatment postactivation improves in vitro development of porcine somatic cell nuclear transfer embryos. Cloning Stem Cells 11: 477-482. [Medline] [CrossRef]

4. Beyhan, Z., Forsberg, E. J., Eilertsen, K. J., Kent-First, M. and First, N. L. 2007. Gene expression in bovine nuclear transfer embryos in relation to donor cell efficiency in producing live offspring. Mol. Reprod. Dev. 74: 18-27. [Medline] [CrossRef]

5. Braddock, J. A., Tasker, S. and Malik, R. 2004. The use of real-time PCR in the diagnosis and monitoring of Mycoplasma haemofelis copy number in a naturally infected cat. J. Feline Med. Surg. 6: 161-165. [Medline] [CrossRef]

6. Burke, F. J. 2009. Copy cat. Dent. Update 36: 457. [Medline]

7. Cervera, R. P., Marti Gutierrez, N., Escorihuela, E., Moreno, R. and Stojkovic, M. 2009. Trichostatin A affects histone acetylation and gene expression in porcine somatic cell nucleus transfer embryos. Theriogenology 72: 1097-1110. [Medline] [CrossRef]

8. Cho, S. K., Kim, J. H., Park, J. Y., Choi, Y. J., Bang, J. I., Hwang, K. C., Cho, E. J., Sohn, S. H., Uhm, S. J., Koo, D. B., et al. 2007. Serial cloning of pigs by somatic cell nuclear transfer: restoration of phenotypic normality during serial cloning. Dev. Dyn. 236: 3369-3382. [Medline] [CrossRef]

9. Costa-Borges, N., Santalo, J. and Ibanez, E. 2010. Comparison between the effects of valproic acid and trichostatin A on the in vitro development, blastocyst quality, and full-term development of mouse somatic cell nuclear transfer embryos. Cell Reprogramm 12: 437-446. [CrossRef]

10. Das, Z. C., Gupta, M. K., Uhm, S. J. and Lee, H. T. 2010. Increasing histone acetylation of cloned embryos, but not donor cells, by sodium butyrate improves their in vitro development in pigs. Cell Reprogram. 12: 95-104. [Medline] [CrossRef]

11. Ding, X., Wang, Y., Zhang, D., Guo, Z. and Zhang, Y. 2008. Increased pre-implantation development of cloned bovine embryos treated with 5-aza-2'-deoxycytidine and trichostatin A. Theriogenology 70: 622-630. [Medline] [CrossRef]

12. Fulka, H., St John, J. C., Fulka, J. and Hozak, P. 2008. Chromatin in early mammalian embryos: achieving the pluripotent state. Differentiation 76: 3-14. [Medline] [CrossRef]

13. Gómez, M. C., Pope, C. E., Biancardi, M. N., Dumas, C., Galiguis, J., Morris, A. C., Wang, G. and Dresser, B. L. 2011. Trichostatin a modified histone covalent pattern and enhanced expression of pluripotent genes in interspecies black-footed cat cloned embryos but did not improve in vitro and in vivo viability. Cell Reprogram 13: 315-329. [Medline] [CrossRef]

14. Hattori, N., Nishino, K., Ko, Y. G., Ohgane, J., Tanaka, S. and Shiota, K. 2004. Epigenetic control of mouse Oct-4 gene expression in embryonic stem cells and trophoblast stem cells. J. Biol. Chem. 279: 17063-17069. [Medline] [CrossRef]

15. Iager, A. E., Ragina, N. P., Ross, P. J., Beyhan, Z., Cunniff, K., Rodriguez, R. M. and Cibelli, J. B. 2008. Trichostatin A improves histone acetylation in bovine somatic cell nuclear transfer early embryos. Cloning Stem Cells 10: 371-379. [Medline] [CrossRef] 
16. Jang, G., Park, E. S., Cho, J. K., Bhuiyan, M. M., Lee, B. C., Kang, S. K. and Hwang, W. S. 2004. Preimplantational embryo development and incidence of blastomere apoptosis in bovine somatic cell nuclear transfer embryos reconstructed with longterm cultured donor cells. Theriogenology 62: 512-521. [Medline] [CrossRef]

17. Kang, H. and Roh, S. 2011. Extended exposure to trichostatin A after activation alters the expression of genes important for early development in nuclear transfer murine embryos. J. Vet. Med. Sci. 73: 623-631. [Medline] [CrossRef]

18. Kang, Y. K., Koo, D. B., Park, J. S., Choi, Y. H., Chung, A. S., Lee, K. K. and Han, Y. M. 2001. Aberrant methylation of donor genome in cloned bovine embryos. Nat. Genet. 28: 173-177. [Medline] [CrossRef]

19. Kishigami, S., Bui, H. T., Wakayama, S., Tokunaga, K., Van Thuan, N., Hikichi, T., Mizutani, E., Ohta, H., Suetsugu, R., Sata, T., et al. 2007. Successful mouse cloning of an outbred strain by trichostatin A treatment after somatic nuclear transfer. J. Reprod. Dev. 53: 165-170. [Medline] [CrossRef]

20. Kishigami, S., Mizutani, E., Ohta, H., Hikichi, T., Thuan, N. V., Wakayama, S., Bui, H. T. and Wakayama, T. 2006. Significant improvement of mouse cloning technique by treatment with trichostatin A after somatic nuclear transfer. Biochem. Biophys. Res. Commun. 340: 183-189. [Medline] [CrossRef]

21. Lan, J., Hua, S., He, X. and Zhang, Y. 2010. DNA methyltransferases and methyl-binding proteins of mammals. Acta Biochim. Biophys. Sin. (Shanghai) 42: 243-252. [Medline] [CrossRef]

22. Li, B., Carey, M. and Workman, J. L. 2007. The role of chromatin during transcription. Cell 128: 707-719. [Medline] [CrossRef]

23. Li, J., Svarcova, O., Villemoes, K., Kragh, P. M., Schmidt, M., Bogh, I. B., Zhang, Y., Du, Y., Lin, L., Purup, S., et al. 2008. High in vitro development after somatic cell nuclear transfer and trichostatin A treatment of reconstructed porcine embryos. Theriogenology 70: 800-808. [Medline] [CrossRef]

24. Li, X., Kato, Y., Tsuji, Y. and Tsunoda, Y. 2008. The effects of trichostatin A on mRNA expression of chromatin structure-, DNA methylation-, and development-related genes in cloned mouse blastocysts. Cloning Stem Cells 10: 133-142. [Medline] [CrossRef]

25. Maalouf, W. E., Liu, Z., Brochard, V., Renard, J. P., Debey, P., Beaujean, N. and Zink, D. 2009. Trichostatin A treatment of cloned mouse embryos improves constitutive heterochromatin remodeling as well as developmental potential to term. $B M C$ Dev. Biol. 9: 11. [Medline] [CrossRef]

26. Marks, P. A., Richon, V. M. and Rifkind, R. A. 2000. Histone deacetylase inhibitors: inducers of differentiation or apoptosis of transformed cells. J. Natl. Cancer Inst. 92: 1210-1216. [Medline] [CrossRef]

27. Miyoshi, K., Mori, H., Mizobe, Y., Akasaka, E., Ozawa, A., Yoshida, M. and Sato, M. 2010. Valproic acid enhances in vitro development and Oct-3/4 expression of miniature pig somatic cell nuclear transfer embryos. Cell Reprogram 12: 67-74. [Medline] [CrossRef]

28. Niemann, H., Tian, X. C., King, W. A. and Lee, R. S. 2008. Epigenetic reprogramming in embryonic and foetal development upon somatic cell nuclear transfer cloning. Reproduction 135: 151-163. [Medline] [CrossRef]

29. Reik, W. 2007. Stability and flexibility of epigenetic gene regulation in mammalian development. Nature 447: 425-432. [Medline] [CrossRef]

30. Rideout, W. M. 3rd., Eggan, K. and Jaenisch, R. 2001. Nuclear cloning and epigenetic reprogramming of the genome. Science 293: 1093-1098. [Medline] [CrossRef]
31. Rybouchkin, A., Kato, Y. and Tsunoda, Y. 2006. Role of histone acetylation in reprogramming of somatic nuclei following nuclear transfer. Biol. Reprod. 74: 1083-1089. [Medline] [CrossRef]

32. Shi, L. H., Ai, J. S., Ouyang, Y. C., Huang, J. C., Lei, Z. L., Wang, Q., Yin, S., Han, Z. M., Sun, Q. Y. and Chen, D. Y. 2008. Trichostatin A and nuclear reprogramming of cloned rabbit embryos. J. Anim. Sci. 86: 1106-1113. [Medline] [CrossRef]

33. Shi, L. H., Miao, Y. L., Ouyang, Y. C., Huang, J. C., Lei, Z. L., Yang, J. W., Han, Z. M., Song, X. F., Sun, Q. Y. and Chen, D. Y. 2008. Trichostatin A (TSA) improves the development of rabbit-rabbit intraspecies cloned embryos, but not rabbit-human interspecies cloned embryos. Dev. Dyn. 237: 640-648. [Medline] [CrossRef]

34. Vaissière, T., Sawan, C. and Herceg, Z. 2008. Epigenetic interplay between histone modifications and DNA methylation in gene silencing. Mutat. Res. 659: 40-48. [Medline] [CrossRef]

35. Wakayama, S., Kishigami, S., Van Thuan, N., Ohta, H., Hikichi, T., Mizutani, E., Yanagimachi, R. and Wakayama, T. 2005. Propagation of an infertile hermaphrodite mouse lacking germ cells by using nuclear transfer and embryonic stem cell technology. Proc. Natl. Acad. Sci. U.S.A. 102: 29-33. [Medline] [CrossRef]

36. Wakayama, T., Tabar, V., Rodriguez, I., Perry, A. C., Studer, L. and Mombaerts, P. 2001. Differentiation of embryonic stem cell lines generated from adult somatic cells by nuclear transfer. Science 292: 740-743. [Medline] [CrossRef]

37. Wang, F., Kou, Z., Zhang, Y. and Gao, S. 2007. Dynamic reprogramming of histone acetylation and methylation in the first cell cycle of cloned mouse embryos. Biol. Reprod. 77: 1007-1016. [Medline] [CrossRef]

38. Wang, F., Ma, Z., Li, Y., Zhu, S., Xiao, Z., Zhang, H. and Wang, Y. 2011. Development of in silico models for pyrazoles and pyrimidine derivatives as cyclin-dependent kinase 2 inhibitors. $J$. Mol. Graph. Model. 30: 67-81. [Medline] [CrossRef]

39. Wang, Y., Su, J., Wang, L., Xu, W., Quan, F., Liu, J. and Zhang, Y. 2011. The effects of 5-aza-2'- deoxycytidine and trichostatin A on gene expression and DNA methylation status in cloned bovine blastocysts. Cell Reprogram 13: 297-306. [Medline] [CrossRef]

40. Wee, G., Shim, J. J., Koo, D. B., Chae, J. I., Lee, K. K. and Han, Y. M. 2007. Epigenetic alteration of the donor cells does not recapitulate the reprogramming of DNA methylation in cloned embryos. Reproduction 134: 781-787. [Medline] [CrossRef]

41. Weissbach, A., Ward, C. and Bolden, A. 1989. Eukaryotic DNA methylation and gene expression. Curr. Top. Cell. Regul. 30: 1-21. [Medline]

42. Wu, J., Wang, S. H., Potter, D., Liu, J. C., Smith, L. T., Wu, Y. Z., Huang, T. H. and Plass, C. 2007. Diverse histone modifications on histone 3 lysine 9 and their relation to DNA methylation in specifying gene silencing. BMC Genomics 8: 131. [Medline] [CrossRef]

43. Yang, F., Hao, R., Kessler, B., Brem, G., Wolf, E. and Zakhartchenko, V. 2007. Rabbit somatic cell cloning: effects of donor cell type, histone acetylation status and chimeric embryo complementation. Reproduction 133: 219-230. [Medline] [CrossRef]

44. Yang, X., Smith, S. L., Tian, X. C., Lewin, H. A., Renard, J. P. and Wakayama, T. 2007. Nuclear reprogramming of cloned embryos and its implications for therapeutic cloning. Nat. Genet. 39: 295-302. [Medline] [CrossRef]

45. Zhang, Z., Wang, J., Niu, W., Ma, M., Jiang, K., Zhu, P. and Ke, B. 2011. Corneal asphericity and its related factors in 1052 Chinese subjects. Optom. Vis. Sci. 88: 1232-1239. [Medline] [CrossRef] 